\title{
Selective Adsorption Behavior of Cesium Ions onto Granite ${ }^{\dagger}$
}

\author{
Akira Kitamuratt, Tadashi Yamamoto ${ }^{t t}$, Hirotake Moriyama ${ }^{t t}$ and Sataro Nishikawa $^{\text {ttt }}$
}

\begin{abstract}
The adsorption behavior of $\mathrm{Cs}^{+}$onto granite was investigated. The distribution coefficient $\left(K_{d}\right)$ of $\mathrm{Cs}^{+}$onto granite was determined in the solution of which $\mathrm{pH}$ was ranged from 2.3 to 10.9 and ionic strength was set at $10^{-2}$ and $10^{-1}$. It is found that the $K_{d}$ values for granite were larger than those for quartz, and the $K_{d}$ values were found to increase with increasing $\mathrm{pH}$ and with decreasing ionic strength. The obtained data were successfully analyzed by an electrical double layer model and the optimum parameter values of the double layer electrostatics and adsorption reactions were obtained. The selective adsorption behavior of $\mathrm{Cs}^{+}$onto the mineral components was discussed, and $\mathrm{Cs}^{+}$were considered to be mainly adsorbed onto feldspars in the granite. Keywords: Radioactive waste management, Radionuclide migration, Cs, Adsorption, Granite, Batch experiment, Distribution coefịcient, Electrical double layer model
\end{abstract}

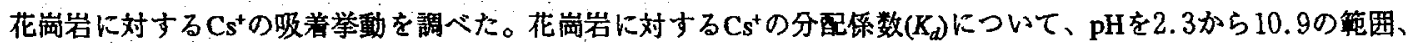

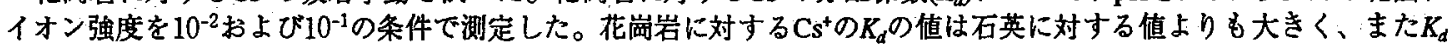
の值はpHの增加引よびイオン强度の減少に伴って增加することが確認された。得られたデータは電気二重層モテル で解析されて良好なフィッティングの結果が得られ、このときの電気二重層の静電的作用を表すパラメー夕および 吸着反応のパラメータが求められた。この解析をとに鉱物成分へのCs の選択的吸着挙動を検討し、C $\mathrm{Cs}^{+}$は花南岩中 において長石に選抧的に吸着されれるとが示唆された。

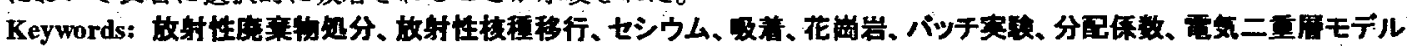

\section{Introduction}

An understanding of radionuclide migration behavior is important for the safety assessment of geologic disposal of radioactive wastes. Many studies have been extensively performed to obtain data for adsorption and diffusion of various radionuclides in soils and rocks. However, the experimental data are usually described by empirical means, and the empirical parameters, e.g. distribution coefficient $\left(K_{d}\right)$, are highly dependent on the chemical conditions of the experimental systems and considered unsatisfactory for a mechanistic modeling of adsorption isotherms[1-3]. Thermodynamic data are required to provide for the safety assessment instead of the empirical parameters.

There are many studies about a solid-solution interface by using an electrical double layer model. In the model, it is assumed that adsorbent surface has specific acid-base characteristics due to hydrolysis. This approach has been coupled with aqueous speciation models in computer codes, and has been successfully applied to describe the equilibrium distributions of some radionuclides between groundwater and mineral surface[4-6]. For its usefulness to determine thermodynamic data, the model may be applied to the other adsorption systems and improved as required[7, 8].

In our previous study, the adsorption behavior of $\mathrm{Cs}^{+}$ onto quartz was successfully analyzed by using an electrical double layer model[9]. The study has obtained parameters such as an inner layer electrostatic capacitance and equilibrium constants and discussed the adsorption mechanism of $\mathrm{Cs}^{+}$onto

† セシウムの花崗岩に対する選択的吸差挙项、 北村暁 (akitam@nucl.eng.osaka-u.ac.jp)、山本忠史、森山裕丈、西川 传太郎

${ }^{\dagger}$ 大阪大学大学院工学研究科原子力工学専攻 Department of Nuclear Engineering, Faculty of Engineering, Osaka University 于565 大阪府吹田市山田丘2-1

t七 京都大学原子炉実験所 Research Reactor Institute, Kyoto University T 590-04 大纳府泉南部能取町野田 quartz. The same method may be applied to other rock samples or minerals.

The present study is an extension of our previous study, and deals with the adsorption behavior of $\mathrm{Cs}^{+}$onto granite powders. Granite is noted as one of the bedrocks proposed for a disposal site of radioactive wastes. There are many studies for the adsorption of $\mathrm{Cs}^{+}$onto rock samples such as granite[1012]. In some literatures it has been shown that $\mathrm{Cs}^{+}$are selectively adsorbed onto biotite in a biotite granite sample[1317]. However, these studies discuss only a comparison of the distribution coefficient among rock samples or mineral components, then the adsorption mechanism has not been described clearly yet. In the present study, distribution coefficients of $\mathrm{Cs}^{+}$and acidity constants of $\mathrm{Na}^{+}$were measured for the granite and its component minerals of microcline and biotite. Then the selective adsorption behavior of $\mathrm{Cs}^{+}$onto granite and the component minerals was analyzed by the similar model to that of Davis et al.[1]

\section{Experimental}

\subsection{Determination of distribution coefficient of Cs onto granite and microcline}

Distribution coefficient $\left(K_{d}\right)$ of $\mathrm{Cs}^{+}$onto granite was determined by a batch method. The granite sample was biotite granite, from Inada, Ibaraki, Japan. The granite sample was crushed to the mesh size of $32 \sim 60$, and the specific surface area was determined to be $0.11 \mathrm{~m}^{2} / \mathrm{g}$ by the BET method. In a polypropylene tube, $0.1 \mathrm{~g}$ of granite powder was added into $4.0 \mathrm{ml}$ of $\mathrm{NaClO}_{4}$ solution containing $\mathrm{Cs}^{+}$. The electrolyte concentration was set at $10^{-2} \mathrm{~mol} / /$ or $10^{-1} \mathrm{~mol} / /$. The concentration of $\mathrm{Cs}^{+}$in the solution was set at $2.5 \times 10^{-6}$ $\mathrm{mol} / \mathrm{l}$ including a radioactive tracer of ${ }^{134} \mathrm{Cs}$. The $\mathrm{pH}$ of the solution was adjusted by either $\mathrm{HClO}_{4}$ or $\mathrm{NaOH}$. The sample was gently contacted with shaking for 7 days at $24 \pm 3^{\circ} \mathrm{C}$ to 
attain the equilibrium. After centrifugation at $5,000 \mathrm{rpm}$ for $10 \mathrm{~min}$, the $\mathrm{pH}$ values were measured. The $604.7 \mathrm{keV} \gamma$ tay radioactivity of ${ }^{134} \mathrm{Cs}$ in the solution was measured. The experiments were performed in an argon filled glove box to avoid the contamination of carbonate.

A batch method was also applied to the determination of the $K_{d}$ of $\mathrm{Cs}^{+}$onto microcline. The experimental setting is same as that of granite except for the concentration of $\mathrm{Cs}^{+}, 1.6$ $\times 10^{-7} \mathrm{~mol} / \mathrm{l}$.

\subsection{Determination of acidity constant of minerals contained in granite}

To determine the acidity constant of minerals contained in granite, such as quartz, feldspar and mica, a batch method or a titration method was used. The method of the determination of acidity constant of quartz has been described elsewhere [9].

For the determination of acidity constant of microcline, a representative of the potassium feldspars, a batch method was used because diffusion effect is expected to be retarded to attain the equilibrium. The crushed microcline sample was obtained from Nihon Chikagaku Co., and the specific surface area was measured to be $0.83 \mathrm{~m}^{2} / \mathrm{g}$ by the BET method. In order to

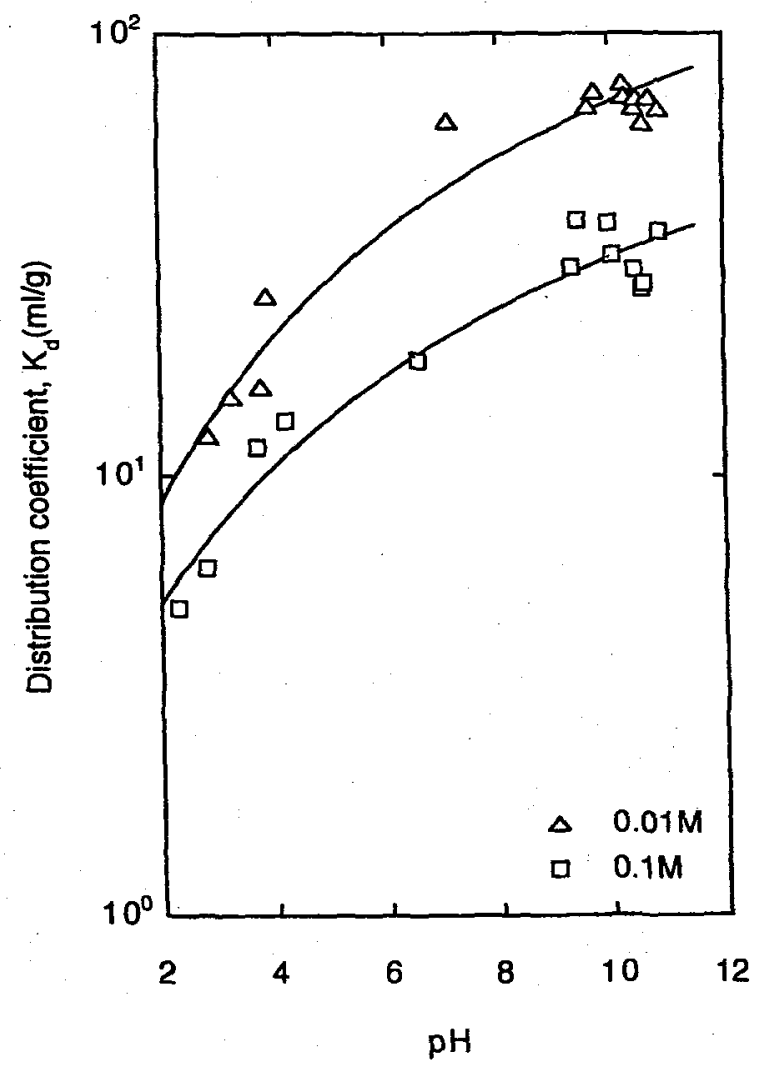

Fig. 1 Distribution coefficient of $\mathrm{Cs}^{+}$ions for granite powders as a function of $\mathrm{pH}$. Marks are the experimental data and curves represent the leastsquares fit of the data by using electrical double layer model. wash out any exchangeable cations before starting the batch experiment, the microcline sample was contacted with 0.5 $\mathrm{mol} / \mathrm{HCl}$ for 1 week, then washed with distilled water and dried at $70^{\circ} \mathrm{C}$. In a polypropylene tube, $0.1 \mathrm{~g}$ of microcline was added into $5.0 \mathrm{ml}$ of $\mathrm{NaCl}$ solution. The electrolyte concentration was set at $10^{-1} \mathrm{~mol} / \mathrm{h}$ or $1 \mathrm{~mol} / \mathrm{l}$. Then a $\mathrm{NaOH}$ solution of $5 \times 10^{-4} \mathrm{~mol} / \mathrm{l}$ solution was added to each sample. The sample was gently contacted with shaking for 7 days at 20 $\pm 3{ }^{\circ} \mathrm{C}$ to attain the equilibrium. After equilibration, the $\mathrm{pH}$ values of each sample were measured.

A titration method was used to determine the acidity constant of biotite, a representative of micas in this study. The biotite sample was obtained from Nihon Chikagaku Co., and the sample sieved into $32 \sim 60$ mesh. In a polypropylene beaker, $1 \mathrm{~g}$ of biotite was mixed with $250 \mathrm{ml}$ of $\mathrm{NaCl}$ solution. The electrolyte concentration was set at $10^{-1} \mathrm{~mol} / /$ or $1 \mathrm{~mol} /$. A NaOH solution of $1.0 \times 10^{-2} \mathrm{~mol} / \mathrm{l}$ was used as a titrant, and the titrant was added at $20 \pm 3{ }^{\circ} \mathrm{C}$ with monitoring $\mathrm{pH}$ value. The $\mathrm{pH}$ values were ranged from 8.2 to 9.2 , in each ionic strength sample.

All of the experiments were performed in an argon filled glove box to avoid the contamination of carbonate and to avoid any effects of carbonate on the $\mathrm{pH}$ of the solution and the surface properties of the adsorbents.

\section{Results and Discussion}

\subsection{Experimental results}

The $K_{d}(\mathrm{ml} / \mathrm{g})$ value was calculated by the following equation ;

$$
K_{d}=\left(A_{0}-A_{f}\right) V /\left(A_{f} W\right)
$$

where $A_{0}(\mathrm{cps} / \mathrm{ml})$ and $A_{f}(\mathrm{cps} / \mathrm{ml})$ denote the counting rates before and after equilibration, $V(\mathrm{ml})$ the volume of the solution and $W(\mathrm{~g})$ the weight of the dried granite sample, respectively.

Figure 1 shows the $K_{d}$ values for granite as a function of $\mathrm{pH}$. As seen in this figure, the $K_{d}$ values increases with increasing $\mathrm{pH}$ and with decreasing ionic strength of the electrolyte solution. By comparing the present results with those for quartz[9], it is found that the $K_{d}$ values for granite are larger than those for quartz.

The surface charge density, $\sigma,\left(\mu \mathrm{C} / \mathrm{cm}^{2}\right)$, is obtained from the following equation[18];

$$
\sigma_{s}=-9650 \mathrm{~A} / \mathrm{S}_{0}
$$

where $A$ denotes the amount of surface hydroxyl ions (meq./g of quartz, microcline or biotite) and $S_{0}$ the specific surface area $\left(\mathrm{m}^{2} / \mathrm{g}\right)$. The calculated surface charge densities of microcline and biotite are plotted against $\mathrm{pH}$ in Figs 2 and 3, respectively. It is observed that the $\sigma$, value increases with increasing $\mathrm{pH}$ and ionic strength.

The $K_{d}$ values are calculated by equation (1). Figure 4 


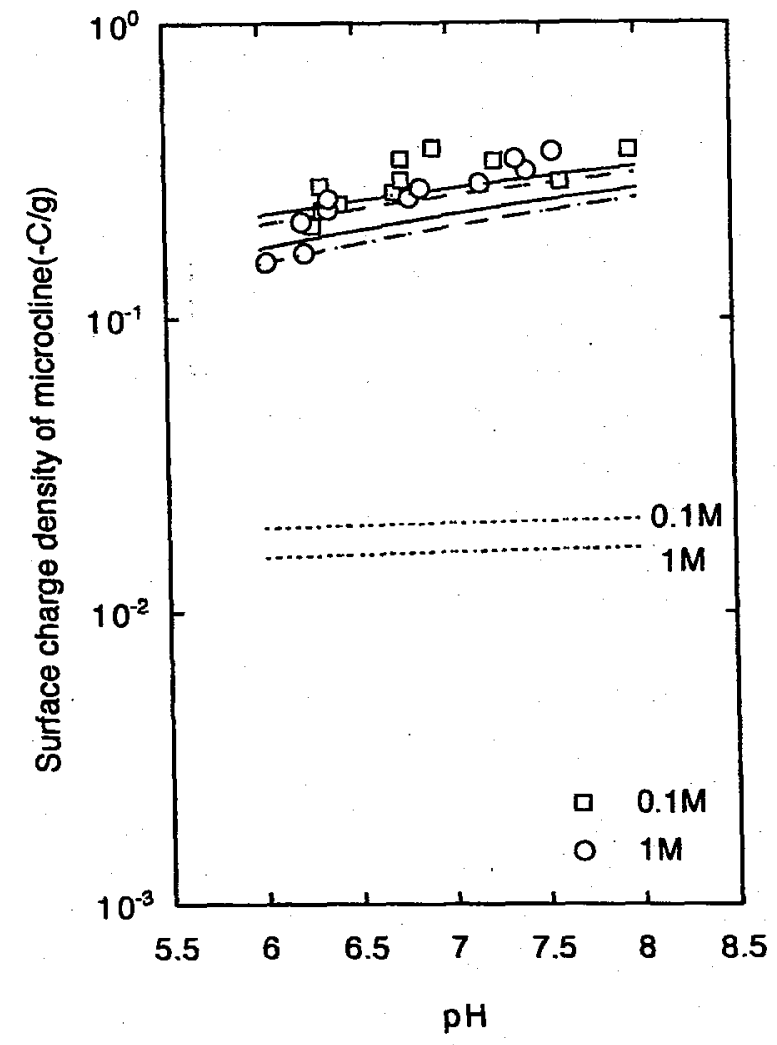

Fig. 2 Surface charge density of microcline as a function of pH. Marks are the experimental data obtained from the measurement of $\mathrm{Na}^{+}$adsorption isotherms and curves represent the least-squares fit of the data to the electrical double layer model. Dashed and dotted curves denote the contribution of the species on the compact Stern layer and in the diffuse layer, respectively, and solid ones the total.

shows the $K_{d}$ values of microcline as a function of $\mathrm{pH}$. The $K_{d}$ value increases with increasing $\mathrm{pH}$ and with decreasing ionic strength of the electrolyte solution, similarly to the $K_{d}$ of Cs for granite (Fig. 1).

\subsection{Electrical double layer model}

Adsorption is considered to the accumulation of solution species at the solid-liquid interface and several adsorption sites are expected to be present at the surface of minerals containing in the granite. In the present study, however, any adsorption site in the minerals is represented by S-OH for simplicity. The hydroxylated surface is mainly responsible for the surface charge as

$$
\begin{gathered}
K_{a 1}^{\text {int }} \\
\mathrm{S}-\mathrm{OH}_{2}^{+} \rightleftarrows \mathrm{S}-\mathrm{OH}+\mathrm{H}_{8}^{+}, \\
K_{a 2}^{\text {int }} \\
\mathrm{S}-\mathrm{OH} \rightleftarrows \mathrm{S}-\mathrm{O}+\mathrm{H}_{8}^{+},
\end{gathered}
$$

where $S$ denotes the metal ions at the surface, $K_{a 1}{ }^{i n t}, K_{a 2}{ }^{i n t}$ are the intrinsic acidity constants of reactions (3) and (4), and the subscript $s$ denotes the surface. In the minerals of quartz,

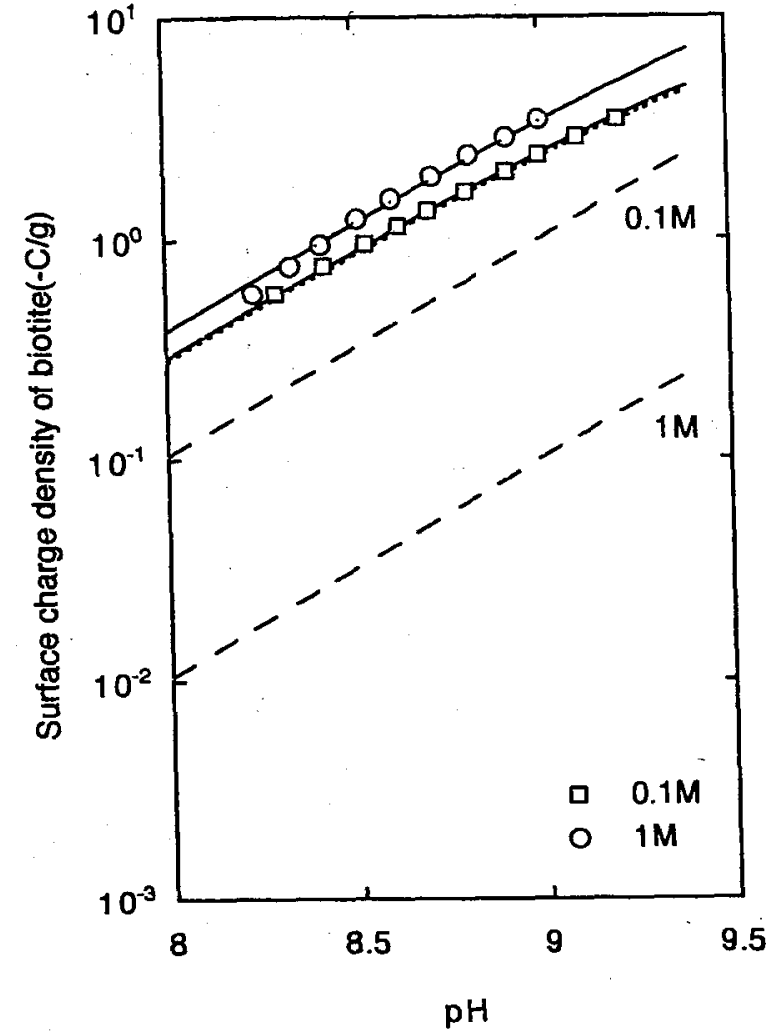

Fig. 3 Surface charge density of biotite as a function of $\mathrm{pH}$. Marks are the experimental data and curves represent the least-squares fit of the data by using electrical double layer model. See the caption in Figure 2 for curves.

microcline and biotite, the points of zero charge, which are $\mathrm{pH}$ values where the net surface charge is zero, is around $2[19,20]$. Thus the surface is negatively charged at near-neutral and basic conditions. By considering the electrostatic nature of the interactions, the adsorption data of $\mathrm{Na}^{+}$and $\mathrm{Cs}^{+}$onto granite or its component minerals may be analyzed by an electrical double layer model[21]. A similar model to that of Davis et al.[1] is thus applied to the presently obtained data.

In their model, it is assumed that the adsorbent surface has specific acid-base characteristics, and that the adsorbate ion is subject to the double layer electrostatics. In addition to the diffuse layer, the compact Stern layer is composed of an inner layer and an outer layer with their own electrostaticcapacitances, $C_{1}$ and $C_{2}$, respectively. Together with reaction (4), the following surface reaction for $\mathrm{Na}^{+}$and $\mathrm{Cs}^{+}$is considered in the present study:

$$
\begin{gathered}
K_{\mathrm{N} a}^{i n t} \\
\mathrm{~S}-\mathrm{O}^{-}+\mathrm{Na}_{\beta}^{+} \rightleftarrows \mathrm{S}-\mathrm{O}^{-}-\mathrm{Na}^{+}, \\
K_{\mathrm{Cs}}^{i n t} \\
\mathrm{~S}^{+} \mathrm{O}^{-}+\mathrm{Cs}_{\beta}{ }^{+} \rightleftarrows \mathrm{S}-\mathrm{O}^{-}-\mathrm{Cs}^{+},
\end{gathered}
$$

where the subscript $\beta$ denotes the plane of counter-ions closest to the surface, i.e., the compact Stern layer. Reactions (5) and 


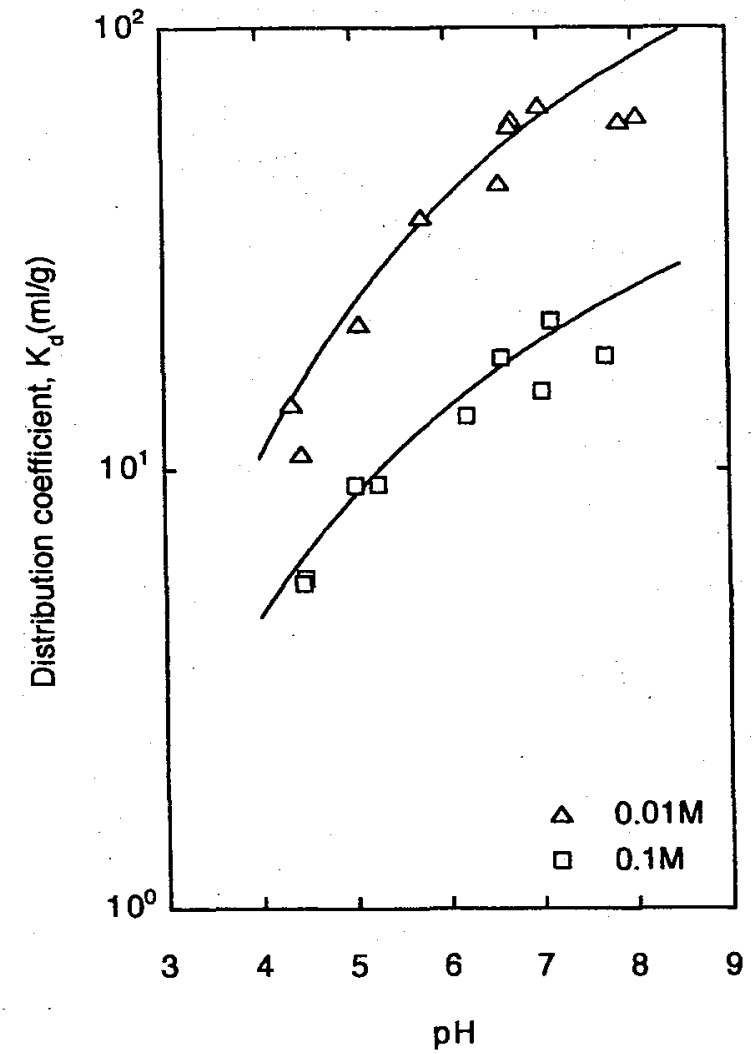

Fig. 4 Distribution coefficient of $\mathrm{Cs}^{+}$ions for microcline powders as a function of $\mathrm{pH}$. Marks are the experimental data and curves represent the leastsquares fit of the data by using electrical double layer model.

(6) may compete with each other in the present system at equilibrium. Equations used in the analysis are thus given as follows:

$$
\begin{aligned}
& K_{a 2}^{\text {int }}=[\mathrm{S}-\mathrm{O}]\left[\mathrm{H}^{+}\right]_{b} \exp [(-\mathrm{e} \psi \mathrm{y}) / k T] /[\mathrm{S}-\mathrm{OH}] \text {, } \\
& \left.K_{\mathrm{Na}^{\text {int }}}^{\text {int }}=\left[\mathrm{S}-\mathrm{O}^{-}-\mathrm{Na}^{+}\right] \exp \left[\left(\mathrm{e}_{\beta}\right) / k T\right] /(\mathrm{S}-\mathrm{OH}]\left[\mathrm{Na}^{+}\right]_{b}\right) \text {, } \\
& K_{\mathrm{Cs}}^{\text {int }}=\left[\mathrm{S}-\mathrm{O}^{-}-\mathrm{Cs}^{+}\right] \exp \left[\left(\mathrm{eq}_{\beta}\right) \mathrm{VTT}\right]\left([\mathrm{S}-\mathrm{OH}]\left[\mathrm{Cs}^{+}\right]_{b}\right) \text {, } \\
& N_{s}=B\left([\mathrm{~S}-\mathrm{OH}]+\left[\mathrm{S}-\mathrm{O}^{-}\right]+\left[\mathrm{S}-\mathrm{O}^{-}-\mathrm{Na}^{+}\right]+\left[\mathrm{S}-\mathrm{O}^{-}-\mathrm{Cs}^{+}\right]\right) \text {, } \\
& \sigma_{s}=-B\left(\left[\mathrm{~S}-\mathrm{O}^{-}\right]+\left[\mathrm{S}^{-} \mathrm{O}^{-}-\mathrm{Na}^{+}\right]+\left[\mathrm{S}-\mathrm{O}^{-}-\mathrm{Cs}^{+}\right]\right) \text {, } \\
& \sigma_{\beta}=B\left(\left[\mathrm{~S}-\mathrm{O}^{-}-\mathrm{Na}^{+}\right]+\left[\mathrm{S}-\mathrm{O}^{-}-\mathrm{Cs}^{+}\right]\right) \text {, } \\
& \sigma_{d}=-11.74 c^{1 / 2} \sinh (e \psi d k T) \text {, } \\
& \sigma_{s}+\sigma_{\beta}+\sigma_{\bar{d}}=0 \text {, } \\
& \psi_{s} \psi_{\beta}=\sigma_{s} / C_{1} \text {, } \\
& \psi_{\bar{\beta}}-\psi_{\overline{\bar{d}}}-\sigma_{d^{\prime}} / C_{2} \\
& B=10^{6} F V / S_{0} \text {, } \\
& K_{d}=10 S_{0}\left[B\left[\mathrm{~S}-\mathrm{O}^{-}-\mathrm{Cs}^{+}\right]+\sigma_{d}\left[\mathrm{Cs}^{+}\right]_{b} /\left(\left[\mathrm{Cs}^{+}\right]_{b}+\left[\mathrm{Na}^{+}\right]_{b}\right)\right] /\left(N_{A} e\left[\mathrm{Cs}^{+}\right]_{b}\right) \text {, }
\end{aligned}
$$

where $K_{\mathrm{Na}}^{\text {int }}$ and $K_{\mathrm{Cs}}^{\text {int }}$ are the intrinsic constants of local equilibrium reactions (5) and (6), respectively, $e$ : the electronic charge; $\psi$ : the variable electrostatic potential in the double layer; $k$ : the Boltzmann constant; $T$ : the absolute temperature; $N_{s}$ : the surface site density; $\sigma$ : the charge density; $c$ : the ionic strength; $F$ : the Faraday constant; $V$ : the liquid volume; $S_{0}$ : the surface area; $N_{A}$ : the Avogadro number, and the subscripts $b$ and $d$ denote the bulk and the diffuse layer, respectively. For the variable electrostatic potential in the electrical double layer, the concentration of each species $X$ in the layer can be related to its bulk solution concentration by the exponential Boltzmann factor as given by $[X]_{i}=[X]_{b} \exp \left(-\epsilon \psi_{i} / k T\right)$, where $i=s, \beta$ or $d$.

Usually, solute ions in the compact Stern layer are only regarded as adsorbed ions. In the present study, however, not only the solute ions in the compact Stern layer but also those in the diffuse layer are regarded as adsorbed ions. In such a batch type experiment as for the charge density measurement, the $\mathrm{Na}^{+}$ions in both the layers are considered to contribute and to give more reasonable fits to the measured values[9].

\subsection{Analysis of charge density data}

In the model of Davis et al.[1], a number of parameters are contained in the equations. Those are $N_{s}, K_{a 2}$ int $, C_{1}, C_{2}$, $K_{\mathrm{N}_{2}}^{\text {int }}$ and $K_{\mathrm{Cs}_{\mathrm{s}} \text {. }}^{\text {int }}$ Because of some uncertainties in the measured values, the surface area $S_{0}$ is also treated as a parameter in the analysis of microcline and biotite. Some of the parameters may be considered to compete with each other, and it is necessary to reduce the number of free parameters for a proper convergence. Before the analysis of $\mathrm{Cs}$ adsorption, the intrinsic acidity constant of the quartz, $K_{a 2}$ int, was determined with the titration data of the surface charge density.

In the analysis, the surface site density of 5 sites $/ \mathrm{nm}^{2}$ [22] was assumed, and the parameters $C_{1}$ and $C_{2}$ were also assumed as $125 \mu \mathrm{F} / \mathrm{cm}^{2}$ and $20 \mu \mathrm{F} / \mathrm{cm}^{2}$, respectively. The $C_{2}$ value of $20 \mu \mathrm{F} / \mathrm{cm}^{2}$ is used in several literatures $[1,2,23]$ since this is a reasonable value for compact layer capacitance on $\mathrm{Hg}$ and $\mathrm{AgI}[24,25]$. The $C_{1}$ value of $125 \mu \mathrm{F} / \mathrm{cm}^{2}$ is also used in some literatures[1, 2] for the analysis of $\mathrm{K}^{+}$adsorption onto silica. Though the $C_{1}$ value is considered to depend on the condition of hydration, a proper convergence of the calculation for $\mathrm{Na}^{+}$adsorption has been obtained with this value; no significant improvement has been attained by treating the $C_{1}$ value as a free parameter.

Figures 2 and 3 show the results of the least squares fits of the experimental data for microcline and biotite, respectively. It can be seen that the $\mathrm{pH}$ and ionic strength dependencies of the surface charge density data are reasonably modeled. In the adsorption for biotite, the $\mathrm{Na}^{+}$ions in the diffuse layer are significantly contributing to the experimental data (Fig. 3). The obtained values of $K_{a 2}{ }^{i n t}, K_{\mathrm{Na}}$ int and $S_{0}$ from the fittings are summarized in Table 1. The parameters of quartz have been obtained in our previous study[9]. Due to its sheet structure, the surface area $S_{0}$ of biotite is much larger than those of other minerals.

In the case of microcline, no proper convergence has been obtained with the measured $S_{0}$ value of $0.83 \mathrm{~m}^{2} / \mathrm{g}$. Then the $S_{0}$ has been treated as a free parameter by taking the estimated $K_{\mathrm{Na}}^{\text {int }}$ value of $10^{-0.56}$, which is an average value of the two for quartz and biotite. It is interesting to note here that 
Table 1 Optimum parameter values derived from the least-squares fit of the electrical double layer model to the experimental data of surface charge density of minerals

\begin{tabular}{lccc}
\hline minerals & quartz & microcline & biotite \\
\hline $\log K_{a 2^{\text {int }}}^{\text {int }}$ & $-6.57 \pm 0.31$ & $-2.12 \pm 1.72$ & $-11.9 \pm 0.1$ \\
$\log K_{\mathrm{Na}}^{ \pm *}$ & $-0.72 \pm 0.35$ & $-0.56^{* *}$ & $-0.44 \pm 0.04$ \\
$S_{0}\left(\mathrm{~m}^{2} / \mathrm{g}\right)$ & 0.51 & $9.1 \pm 3.5$ & $(2.8 \pm 0.5) \times 10^{3}$ \\
\hline$\chi^{2 *}$ & 0.021 & 0.23 & 0.006
\end{tabular}

The $\chi^{2}$ value denotes a variance between experimental data and calculated values.

** The $K_{\mathrm{Na}}^{\text {int }}$ value determined for $\mathrm{Na}^{+}$adsorption onto microcline was used in the analyses of quartz and biotite. See text for details.

Table 2 Optimum parameter values derived from the least-squares fit of the electrical double layer model to the experimental data of distribution coefficient of Cs onto rock samples

\begin{tabular}{lcc}
\hline samples & granite & microcline \\
\hline$C_{1}\left(\mu \mathrm{F} / \mathrm{cm}^{2}\right)$ & $4.65 \pm 0.36$ & $14.3 \pm 1.9$ \\
$\log K_{a 2}^{\text {int }}$ & $-2.12^{*}$ & $-2.12^{*}$ \\
$\log K_{\mathrm{Na}}^{\text {int }}$ & $0.62 \pm 0.13$ & $-1.01 \pm 0.16$ \\
$\log K_{\mathrm{C}_{s}}^{\text {int }}$ & $4.96 \pm 0.12$ & $4.12 \pm 0.18$ \\
$S_{0}\left(\mathrm{~m}^{2} / \mathrm{g}\right)$ & 1.1 & $9.1^{*}$ \\
\hline & & \\
\hline
\end{tabular}

The $K_{a 2}{ }^{\text {int }}$ and $S_{0}$ values determined for $\mathrm{Na}^{+}$adsorption onto microcline were used in the analysis of $\mathrm{Cs}^{+}$adsorption. See text for details.

the $K_{\mathrm{Na}}{ }^{i n t}$ values of both minerals are almost the same as shown in Table 1. It may be due to the electrostatic nature of the interaction between the $\mathrm{Na}^{+}$and the surface, and no specific interaction is considered in this case.

\subsection{Analysis of Cs adsorption}

The parameters determined for the $\mathrm{Na}^{+}$adsorption have been used for the analysis of the $\mathrm{Cs}^{+}$adsorption. In the analysis, the surface site density of 5 sites $/ \mathrm{nm}^{2}$ and the $C_{2}$ value of $20 \mu \mathrm{F} / \mathrm{cm}^{2}$ are assumed in the calculations. However, the $C_{1}$ value of $125 \mu \mathrm{F} / \mathrm{cm}^{2}$ and the $K_{\mathrm{Na}}^{\text {int }}$ values have not been found to be consistent with the experimental data of Fig. 1 and the calculation has not properly converged with these values. They are thus treated as free parameters for a proper convergence in the present study.

The least square fitting has been examined by using the acidity constant $K_{a 2}{ }^{i n t}$ derived from the results for quartz (log $\left.K_{a 2}^{i n t}=-6.57\right)$, microcline (-2.12) and biotite (-11.9). Only the calculation using $\log K_{a 2}^{\text {int }}=-2.12$ has properly converged to the experimental result of Fig. 1. Figure 1 shows the result of the least square fits of the experimental data to the model. It can be seen that the $\mathrm{pH}$ and ionic strength dependencies of the adsorption data are well modeled. It may be noted that, in the case of $\mathrm{Cs}^{+}$, the contribution of the ions in the diffuse layer is negligibly small while the $\mathrm{Na}^{+}$ions in the diffuse layer are significantly contributing to the experimental data for quartz and those for biotite. The obtained parameter values $C_{1}, K_{a 2}$ int, $K_{\mathrm{Na}}^{\text {int }}$ and $K_{\mathrm{Cs}}^{\text {int }}$ are summarized in Table 2. In the analysis the $S_{0}$ value of granite is assumed to be $1.1 \mathrm{~m}^{2} / \mathrm{g}$, which is 10 times larger than the measured value of $0.11 \mathrm{~m}^{2} / \mathrm{g}$, by considering the similar difference in the $S_{0}$ value of microcline (Table 1).

To confirm the acidity constant $K_{a 2}{ }^{\text {int }}$ of $10^{-2.12}$, the least square fitting has been also applied to the adsorption data of $\mathrm{Cs}^{+}$onto microcline. Figure 4 shows the result of the least square fits of the experimental data to the model, and the obtained parameter values $C_{1}, K_{a 2}{ }^{i n t}, K_{\mathrm{Na}}{ }^{i n t}$ and $K_{\mathrm{Cs}}{ }^{i n t}$ are 
Table 3 Distribution coefficients $\left(K_{d}\right)$ of $C s$ onto quartz, microcline and biotite[26]. (Aqueous phases synthetic groundwater, pH 8.2; nuclide concentration $<10^{6} \mathrm{~mol} / \mathrm{l}$ )

\begin{tabular}{lc}
\hline minerals & $K_{d}(\mathrm{ml} / \mathrm{g})$ \\
\hline quartz & 1 \\
microcline & 177 \\
biotite & 650 \\
\hline
\end{tabular}

summarized in Table 2. The parameter values are the same as in the analysis of $\mathrm{Cs}^{+}$onto granite. The fitting has been properly converged, and the acidity constant of microcline of $10^{-2.12}$ is considered to be acceptable for microcline.

\subsection{Adsorption mechanism of Cs onto granite}

There are some literatures dealing with the adsorption of Cs onto granite. The distribution coefficient of Cs onto biotite has been reported to be relatively large compared with those onto feldspars and quartz[16], and $\mathrm{Cs}^{+}$ions are observed to be adsorbed onto biotite selectively by using autoradiography and color image technique[17]. Distribution coefficients of $\mathrm{Cs}$ onto quartz, microcline and biotite are summarized in Table 3[26]. However, the specific surface area of biotite is expected to be so large that there are many adsorption sites in a unit of weight, and there is no evidence whether the Coulomb interaction between the $\mathrm{Cs}^{+}$ion and the adsorption site of biotite is so strong. The adsorption mechanism of granite will be discussed here.

As mentioned above, only the calculation using log $K_{a 2}^{\text {int }}=-2.12$ has properly converged. This result suggests that the adsorption behavior of $\mathrm{Cs}$ onto granite is similar to those onto microcline. In fact, the obtained parameters in the analysis of granite are very similar to those of microcline.

As shown in Table 2, the $C_{1}$ value has been obtained to be $4.65 \pm 0.36$ in the analysis of granite and to be $14.3 \pm 1.9$ in that of microcline. Both values are found to be smaller than those of such alkali metal ions as $\mathrm{Na}^{+}$in the literatures[1,2]. The reason why the $C_{1}$ value in the analysis of $\mathrm{Cs}^{+}$adsorption is smaller than that of $\mathrm{Na}^{+}$has been reported already[9] ; the $C_{1}$ value for the adsorption of differently hydrated ions will be different because of different positions of the compact Stern layers.

Also, the $K_{\mathrm{Cs}}^{\text {int }}$ values obtained from granite and microcline are similar to each other as well as the $K_{\mathrm{Na}}^{\text {int }}$ values. This suggests that the adsorption mechanism of $\mathrm{Cs}^{+}$onto granite and microcline may be similar to each other. In the present case, $\mathrm{Cs}$ ions seem to be mainly adsorbed onto the feldspar of granite.

The present results are somewhat different from the literature ones in which the $\mathrm{Cs}$ ions have been suggested to be selectively adsorbed onto the biotite of granite. For this difference, however, a possible explanation may be given as follows. In the case of the study of Akiba et al.[16], the distribution coefficient, $K_{d}$, of $\mathrm{Cs}^{+}$for biotite was found to be much larger than that for feldspar. The large difference in the distribution coefficient is due to a large difference in the specific surface area between both minerals (Table 1), although it was not measured in their study. A similar explanation might be applied to the radiographic study of Tsukamoto and Ohe[17] who observed that $\mathrm{Cs}^{+}$was selectively distributed onto biotite in granite. In spite of the larger specific area of biotite, its abundance is usually very low in granite compared with that of feldspar. They have observed a selective distribution of $\mathrm{Cs}^{+}$ onto biotite. However, it does not necessarily mean that $\mathrm{Cs}^{+}$ ions are mainly adsorbed onto biotite in granite. Due to large specific surface area, the amount of $\mathrm{Cs}^{+}$onto biotite is apparently larger than that onto feldspar. The enrichment of $\mathrm{Cs}^{+}$onto biotite is not due to highly selective adsorption of $\mathrm{Cs}$ but its large specific surface area. The present results are thus consistent with the observations in the literatures. For confirmation, further studies are necessary to understand the relationship between the amount of $\mathrm{Cs}^{+}$and the specific surface area of each component mineral in granite.

\section{Conclusions}

The distribution coefficient $\left(K_{d}\right)$ of Cs onto granite and the surface charge densities of microcline and biotite was determined by a batch method. The $K_{d}$ values are highly dependent on $\mathrm{pH}$ and ionic strength. The obtained data were successfully analyzed by an electrical double layer model and the optimum parameter values of the double layer electrostatics and adsorption reactions were obtained. The parameter values for granite were found to be very similar to those for microcline, and $\mathrm{Cs}^{+}$were considered to be mainly adsorbed onto feldspars in the granite.

\section{References}

[1] Davis, J. A. et al.: Surface ionization and complexation at the oxide/water interface I. computation of electrical double layer properties in simple electrolytes. J. Colloid Interface Sci. 63, 480 (1978).

[2] James, R. O., Parks, G. A.: Characterization of aqueous colloids by their electrical double layer and intrinsic surface chemical properties. Surface Colloid Sci. 12, 119-216 (1982).

[3] Davis, J. A., Kent, D. B.: Surface Complexation Modeling in Aqueous Geochemistry. Reviews in Mineralogy (Hochella, M. F. and White, A. F. Eds.) Mineralogical Society of America 23, pp.177-260 (1990).

[4] Westall, J. C. et al.: MINEQL: A computer program for the calculation of chemical equilibrium composition of aqueous systems. Tech. Note 18, Dept. of Civil Eng., Mass Inst. Tech., Cambridge, MA (1976).

[5] Brown, D. S., Allison, J. D.: MINTEQA1, Equilibrium 
metal speciation model: A user's manual, EPA/600/387/012, U. S. Environ. Protecti. Agency, Athens, GA (1987).

[6] Papelis, C. et al.: HYDRAQL: A program for the computation of chemical equilibrium composition of aqueous batch systems including surface complexation modeling of ion adsorption at the oxide/water interface. Tech. Rept. 306, Dept. of Civil Eng. Stanford University, Stanford, CA (1988).

[7] Silva, R. J., Nitsche, H.: Actinide environmental chemistry. Radiochim. Acta 70/71, 377-396 (1995).

[8] Moulin, V. et al.: Actinide sorption at oxide-water interfaces: application to $\alpha$-alumina and amorphous silica. Appl Geochem. Suppl. Issue No. 1, 163-166 (1992).

[9] Kitamura, A. et al.: Analysis of adsorption behavior of cesium onto quartz using electrical double layer model. $J$. Nuch Sci. Technol. 33, 840-845 (1996).

[10] Skagius, K. et al.: A study of strontium and cesium sorption on granite. Nucl. Technol, 59 , 302-313 (1982).

[11] Shimooka, K et al.: Measurement of diffusion and sorption of radionuclides in rocks. $J$. Nucl. Sci. Technol. 22, 833-840 (1985).

[12] Idemitsu, $\mathrm{K}$. et al.: Migration of cesium, strontium and cobalt in water-saturated inada granite. J. Nucl. Sci. Technol. 29, 454-460 (1992).

[13] Torstenfelt, B. et al.: Sorption of strontium and cesium on rocks and minerals. Chem. Geol. 36, 123-137 (1982).

[14] Vandergraaf, T. T. et al.: The use of autoradiography in determining the distribution of radionuclides sorbed on thin section of plutonic rocks from the Canadian Shield. Chem. Geol. 36, 139-154 (1982).

[15] Allard, B. et al.: Migration of trace elements into water- exposed natural fissure surface of granitic rock. Chem. Geol. 49, 31-42 (1985).

[16] Akiba, K. et al.: Distribution coefficient of cesium and cation exchange capacity of minerals and rocks. J. Nucl. Sci. Technol. 26, 1130-1135 (1989).

[17] Tsukamoto, M., Ohe, T.: Effects of biotite distribution on cesium diffusion in granite. Chem Geol. 107, 29-46 (1993).

[18] Bolt, G H.: Determination of the charge density of silica sols. J. Phys. Chem 61, 1166-1169 (1957).

[19] Stumm, W., Morgan, J. J.: Aquatic Chemistry, 2nd edn. Wiley Interscience, New York (1981).

[20] Leja, J.: Surface Chemistry of Froth Flotation, Plenum Press, New York (1982).

[21] Stumm, W., Morgan, J. J.: Aquatic Chemistry, 3rd edn. Wiley Interscience, New York (1996).

[22] Armistead, C. G et al.: The surface hydroxylation of silica. J. Phys. Chem 73, 3947-3953 (1969).

[23] Silva, R. J. et al.: Theoretical and experimental evaluation of waste transport in selected rocks. In: Waste Isolation Safety Assessment Program. PNL-SA8571, pp.249-351 (1979).

[24] Stumm, W. et al.: Specific chemical interaction affecting the stability of dispersed systems. Croat. Chem. Acta 42 , 223-245 (1970).

[25] Lyklema, J., Overbeek J. T. G. Electrochemistry of silver iodine; the capacity of the double layer at the silver iodine-water interface. J. Colloid Sci. 16, 595-608 (1961).

[26] Torstenfelt, B. et al.: Radionuclide migration into natural fracture surfaces of granitic rock. Mat. Res. Soc. Symp. Proc. 15, 339-346 (1983). 